In Search of the Lost Decade 



\title{
In Search of the Lost Decade
}

Everyday Rights in Post-Dictatorship Argentina

\author{
Jennifer Adair
}

阳

UNIVERSITY OF CALIFORNIA PRESS 
University of California Press, one of the most distinguished university presses in the United States, enriches lives around the world by advancing scholarship in the humanities, social sciences, and natural sciences. Its activities are supported by the UC Press Foundation and by philanthropic contributions from individuals and institutions. For more information, visit www.ucpress.edu.

University of California Press

Oakland, California

(C) 2020 by Jennifer Adair

Library of Congress Cataloging-in-Publication Data

Names: Adair, Jennifer, 1977- author.

Title: In search of the lost decade : everyday rights in post-dictatorship Argentina / Jennifer Adair.

Description: Oakland, California : University of California Press, [2020] | Includes bibliographical references and index.

Identifiers: LCCN 2019019904 (print) | LCCN 2019980965 (ebook) | ISBN 9780520305175 (cloth) | ISBN 9780520305182 (paperback) | ISBN 9780520973282 (ebook)

Subjects: LCSH: Argentina-Politics and government-1983-2002. | Argentina-Economic conditions-1983- | Argentina-Social conditions-1983-

Classification: LCC F2849.2 .A29 2020 (print) | LCC F2849.2 (ebook) | DDC $982.06-\mathrm{dc} 23$

LC record available at https://lccn.loc.gov/2019019904

LC ebook record available at https://lccn.loc.gov/2019980965

Manufactured in the United States of America

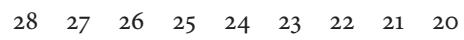


For Julián and Elio 
